November 2000 - NREL/SR-550-28995

\title{
Solar-Based Rural Electrification and Microenterprise Development in Latin America: A Gender Analysis
}

Julie A. Smith

Boston, Massachusetts

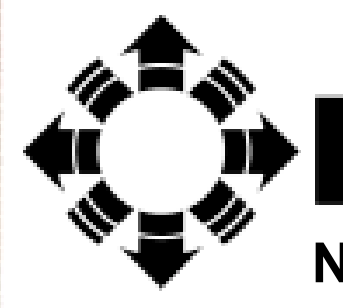

National Renewable Energy Laboratory

1617 Cole Boulevard

Golden, Colorado 80401-3393

NREL is a U.S. Department of Energy Laboratory

Operated by Midwest Research Institute • Battelle • Bechtel

Contract No. DE-AC36-99-G010337 


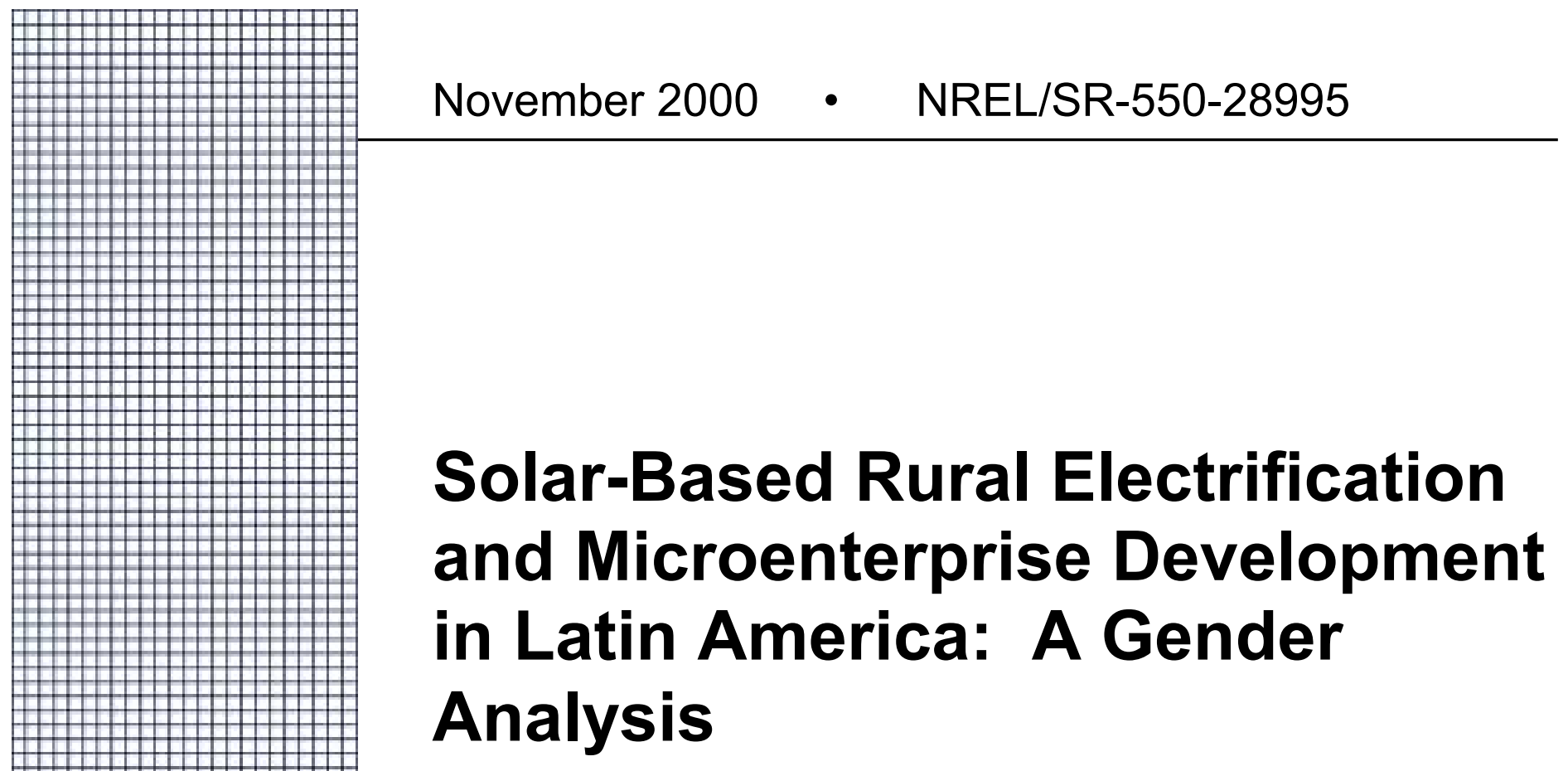

Julie A. Smith

Boston, Massachusetts

NREL Technical Monitor: Barbara C. Farhar, Ph.D.

Prepared under Purchase Order No. 162244

This report can be viewed online at http://www.nrel.gov/docs/fy01osti/28995.pdf

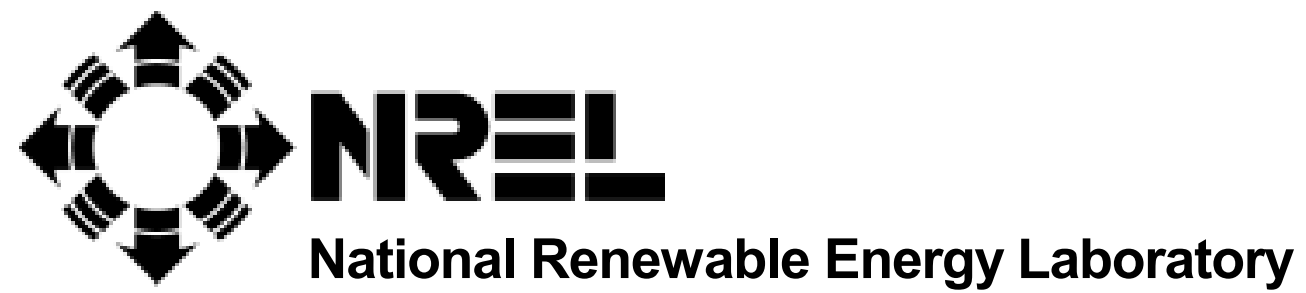

1617 Cole Boulevard

Golden, Colorado 80401-3393

NREL is a U.S. Department of Energy Laboratory

Operated by Midwest Research Institute • Battelle • Bechtel

Contract No. DE-AC36-99-G010337 
Submitted by the subcontractor and received no editorial review at NREL

\section{NOTICE}

This report was prepared as an account of work sponsored by an agency of the United States government. Neither the United States government nor any agency thereof, nor any of their employees, makes any warranty, express or implied, or assumes any legal liability or responsibility for the accuracy, completeness, or usefulness of any information, apparatus, product, or process disclosed, or represents that its use would not infringe privately owned rights. Reference herein to any specific commercial product, process, or service by trade name, trademark, manufacturer, or otherwise does not necessarily constitute or imply its endorsement, recommendation, or favoring by the United States government or any agency thereof. The views and opinions of authors expressed herein do not necessarily state or reflect those of the United States government or any agency thereof.

Available electronically at http://www.doe.gov/bridge

Available for a processing fee to U.S. Department of Energy and its contractors, in paper, from:

U.S. Department of Energy

Office of Scientific and Technical Information

P.O. Box 62

Oak Ridge, TN 37831-0062

phone: 865.576 .8401

fax: 865.576 .5728

email: reports@adonis.osti.gov

Available for sale to the public, in paper, from:

U.S. Department of Commerce

National Technical Information Service

5285 Port Royal Road

Springfield, VA 22161

phone: 800.553.6847

fax: 703.605.6900

email: orders@ntis.fedworld.gov

online ordering: http://www.ntis.gov/ordering.htm 


\section{Contents}

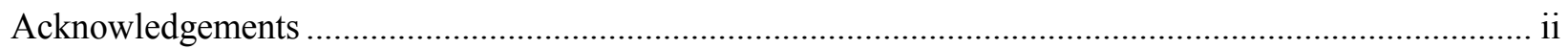

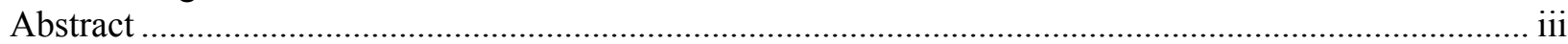

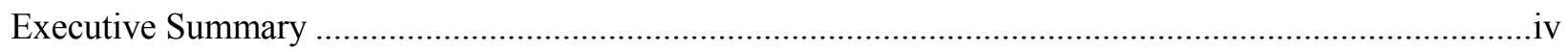

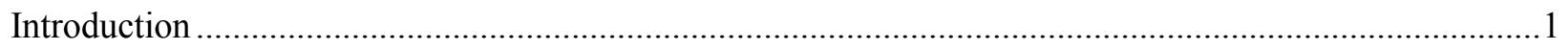

The Rural Energy Situation in Developing Countries ............................................................ 1

Women's Participation in Energy Development .......................................................................2

Decentralized Power: A Solution for Rural Energy Needs .........................................................5

Solar-Based Rural Electrification: A Case Study ..............................................................................

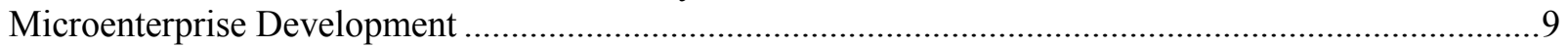

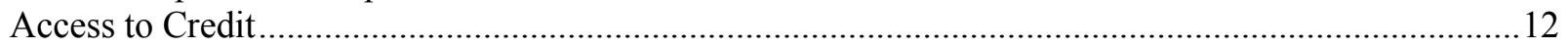

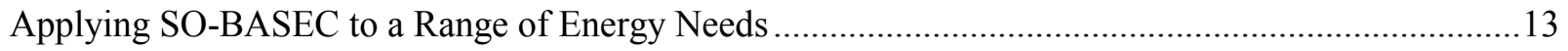

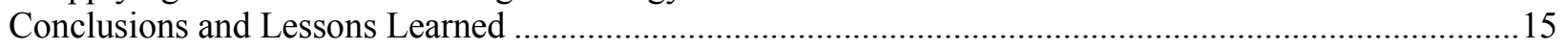

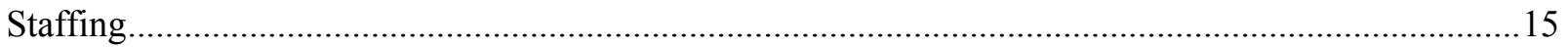

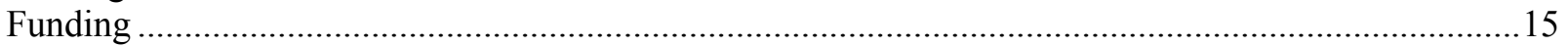

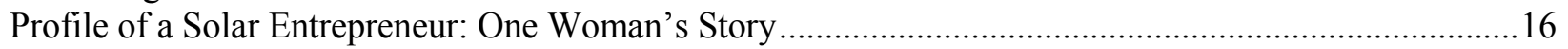

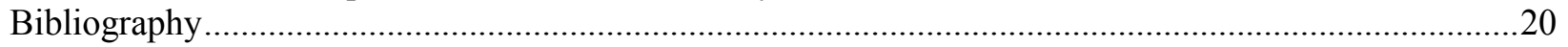

\section{List of Figures}

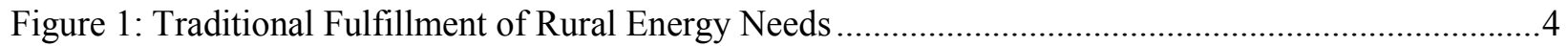

Figure 2: Matching Energy Technology and Rural Need (Dispersed Population)..................................... 7

Figure 3. Enersol's Solar-Based Rural Electrification Model ............................................................... 12 


\section{Acknowledgements}

The National Renewable Energy Laboratory (NREL) sponsored this paper.

The contents of the case study are the result of the author's experiences while working on decentralized renewable energy projects first as a Peace Corps Volunteer in the Dominican Republic and later as an Enersol employee. The study also reflects the valuable contributions of other Enersol staff.

Special acknowledgement is extended to Ms. Ana Cristina Zepeda de Servellon, Executive Director of the Solar Energy Development Association (Asociación para el Desarrollo de la Energía Solar - Honduras; ADESOL-Honduras), an Enersol affiliate in Honduras, for presenting this paper at the World Renewable Energy Congress in Florence, Italy, in September 1998 and to Philip Covell, Enersol's Executive Director, for his valuable contribution and keen proofreading skills. Credit must also be given to Richard Hansen, Shannon Graham, Cynthia Knowles and John Stevens who each in their own way challenged the author to contemplate energy and gender issues amidst the frenzy of life and work in this grassroots movement. A personal thanks also to Thomas Galvin.

This paper would never have been possible were it not for the insight, guidance, and support of Dr. Barbara C. Farhar of the National Renewable Energy Laboratory. For these, I am truly grateful.

The opinions expressed within this study, as well as any inaccuracies, is the responsibility of the author. 


\section{Abstract}

Worldwide, an estimated 1.5 to 2 billion people do not have access to electricity, including 100 million in the Latin America region. Depending on the country, 30 to $90 \%$ of this unelectrified Latin American population lives in rural areas where geographic remoteness and low energy consumption patterns may preclude the extension of the conventional electricity grid. Women are heavily impacted by the energy scarcity given their role as primary energy procurers and users for the household, agricultural and small industrial subsectors in developing countries. As a result, women spend disproportionately more time engaged in energy-related activities like carrying water and searching for cooking fuel.

This paper describes the use of decentralized renewable energy systems as one approach to meet the energy needs of rural areas in Latin America. It outlines the advantages of a decentralized energy paradigm to achieve international development goals, especially as they relate to women. The paper studies Enersol Associates, Inc.'s Solar-Based Rural Electrification model as an example of a decentralized energy program that has merged energy and development needs through the local involvement of energy entrepreneurs, non-governmental organizations and community members. 


\section{Executive Summary}

Approximately one third of the world's population lack access to modern energy supplies and services to meet their daily needs. Electricity is unknown in the daily lives of approximately 1.5 to 2 billion people, and over 2 billion people continue to meet their cooking needs with traditional fuels. ${ }^{1}$ The vast majority of this population lives in rural areas of developing countries. Over 100 million people in Latin America and the Caribbean (LAC) that do not have electricity, with 30 to 90 percent, depending on the country, living in rural areas. ${ }^{2}$

Recent reports confirm what international development practitioners have long suspected: that, in developing countries, "women are the group most affected by energy scarcity and related environmental degradation." ${ }^{3}$ This is because women are intimately tied to energy given their roles as primary procurers and users of most energy sources for the household, agricultural, and small industrial subsectors in developing countries. In rural areas, women spend disproportionately more time than men engaged in survival activities such as firewood collection, water hauling, food processing and cooking. In Latin America, $40 \%$ of rural women are affected by fuelwood scarcity and $45 \%$ are touched by water scarcity. Worldwide, the median time for collecting water stands at 1.6 hours per day in the dry season. While this exertion of human energy goes largely "unmeasured, nonmonetized and unrecorded" in international energy statistics, it nonetheless is abundantly evident when examining health, economic and quality of life indicators at the micro level. ${ }^{4}$

To address the pressing energy needs in remote area of developing countries, several energy schemes have been deployed, not least of which is the extension of conventional electricity grids. As an alternative, one innovative approach - decentralized energy delivery - is gaining significant attention. Decentralized energy is generated and supplied directly at the end-use location eliminating the need for distribution and transmission infrastructure. Decentralized systems often use renewable energy technologies because such technologies are suited to the levels of power needed, can take advantage of local resources (sun, wind, water) and are cost competitive when compared to expanding the conventional grid into remote areas.

Decentralized renewable energy systems are attractive because they can target a particular energy need, be mobilized relatively quickly, are modular in nature allowing for expansion or reduction based on need and economic means, can be individually or communally obtained and are environmentally sound at both the local and global level. Of perhaps greater importance is the fact that decentralized systems keep the energy system close to the end user, allowing the end user direct control of acquisition, design, placement and consumption decisions. This is especially relevant to women, as they are often exert less control over utility-centered grid systems. Decentralization holds tremendous potential for an improved quality of life for women. Specifically, such systems ease the time commitment and human energy required to meet

\footnotetext{
${ }^{1}$ Reddy, Amulya K.N., Robert H. Wiliams, Thomas B. Johansson, (1997). Energy After Rio: Prospects and Challenges. New York: United Nations Publications.

${ }^{2}$ Country Profiles: Renewable Energy and Energy Efficiency in Latin America and the Caribbean (1995). U.S. Export Council for Renewable Energy. xviii.

${ }^{3}$ Becherer Hanan, Jean, ed. (1988). Women and Energy, The International Network: Policies and Experience. Washington, DC: The World Bank.

${ }^{4}$ Reddy, 16.
} 
daily needs, while also elevating the imperative decision-making role women play to ensure the systems' appropriate use.

While the decentralized paradigm of energy delivery is gaining favor in rural areas of developing countries, the successful implementation of such systems requires a keen understanding of local energy needs and preferences, a sensitivity to the local cultural and economic realities, and an understanding of the technology. Enersol Associates, Inc. ("Enersol") has developed a successful implementation model for decentralized renewable energy. Enersol is a U.S.-based, nonprofit international development organization founded in 1984 to improve the quality of life in rural areas of developing countries by fostering the use of solar energy for rural electrification. The model, known as SOlar-BASed Rural Electrification Concept, or SO-BASEC for short, initially focused on disseminating residential photovoltaic (or solar-electric) systems to rural households in the Dominican Republic via local market and institutional mechanisms. The model has been expanded over the past decade to encompass other energy needs for potable and agricultural water, cooking and park and buffer zone area management.

Enersol's success is grounded in its ability to leverage indigenous resources and knowledge by empowering local nonprofit partners to be drivers of information dissemination, training and financing while at the same time enabling entrepreneurial forces to drive hardware availability and system installation. In addition, Enersol uses its programs to encourages governmental and aid agencies to visualize an environmentally viable, decentralized energy future.

Enersol's work is not focused exclusively on women in energy and the current inclusion of women in all project stages has been an evolutionary process. Enersol's programs are an interesting review because, while much of the focus on women was deliberate from the outset, over the years, external as well as internal forces have influenced the inclusion of gender considerations in the model's development. Positive internal influences include the early balancing of female and male staff members in each discipline and geographic region and conscious decisions to address women when discussing energy options. External influences include the provision of funds for the express purpose of sponsoring gendercentered financing and training activities and participation in national organizations that mandate gender standards.

Among the lessons to be gleaned from Enersol's experiences are the challenges organizations faces in incorporating women into market-driven development projects. Enersol's focus on using micro enterprises to disseminate and maintain decentralized energy systems has caused the organization to examine creative ways first, to attract women to entrepreneurial ventures and second, to help them confront the cultural constraints inherent in participation in such a mobile and traditionally male-focused endeavor. Enersol's credit activities encourage women to become borrowers in order to finance the purchase of energy systems. All of these activities seek to harness the power and benefits of women as agents of change. Enersol is far from asserting that it has a globally applicable solution to this problem, but the lessons learned from its experience generate interesting and useful dialogue. 


\section{Introduction}

\section{The Rural Energy Situation in Developing Countries}

Approximately one third of the world's population lack access to modern energy supplies and services to meet their daily needs. Electricity is unknown in the daily lives of approximately 1.5 to 2 billion people, and over 2 billion people continue to meet their cooking needs with traditional fuels. ${ }^{5}$ The vast majority of this population live in rural areas of developing countries, including the 100 million people in the Latin America and the Caribbean (LAC) that lack electricity. From 30 to 90 percent of this 100 -million unelectrified population live in rural areas. ${ }^{6}$

The challenge thus becomes finding an efficient and economically feasible way to provide modern energy options in some of the most remote and needy regions of the world. A projected $100 \mathrm{GW}$ of increased conventional electrical capacity for LAC will be installed over the next decade in addition to the extension of transmission and distribution systems. ${ }^{7}$ However, it is likely that this infrastructure improvement will be largely absorbed by demand growth within residential and industrial areas already connected to the electricity grid system. The rural areas that do not yet benefit from energy services tend to have a low population density, low energy demand and are located very far from the energy service networks. These factors greatly increase the cost of extending services and reduce the chance that rural areas will receive conventional energy services within the foreseeable future, leaving energy planners, local development organizations, entrepreneurs and the rural communities themselves to confront serious energy deficiencies, and its consequences, in remote outlying areas.

The rural communities that are beyond the reach of the electric grid or cooking fuel distribution network are forced to rely upon crude power sources and their own ingenuity and dedication to provide for their minimal energy needs. In the Dominican Republic, families use dangerous and unhealthy kerosene lamps or candles, at a cost of between $\$ 3$ and $\$ 11$ per $\mathrm{kWh}$ equivalent. These kerosene lamp emit 0.2 lumens per watt of energy, compared to the 10 lumens per watt emitted by a 40 watt incandescent bulb found in most electrified homes. ${ }^{8}$ The same Dominican families listen to small radios powered by poor quality, disposable dry cell batteries, costing between $\$ 30$ and $\$ 60 / \mathrm{kWh}$. Television sets, a source of pride as well as much needed information and entertainment in many rural areas, are often powered by poor-quality car batteries. These batteries are fully discharged then hauled, on the backs of motorcycles or donkeys, to a recharging center on a weekly or biweekly basis at a significant time cost and economic cost of between $\$ 2.50$ to $\$ 3.50$ per $\mathrm{kWh}^{9}$. Refrigeration is practically nonexistent except for the occasional propane-

\footnotetext{
${ }^{5}$ Reddy, Amulya K.N., Robert H. Williams, Thomas B. Johansson, (1997). Energy After Rio: Prospects and Challenges. New York: United Nations Publications.

${ }^{6}$ Country Profiles: Renewable Energy and Energy Efficiency in Latin America and the Caribbean (1995). U.S. Export Council for Renewable Energy. xviii.

${ }^{7}$ Moore, Taylor. (July/August 1995). Developing Countries on a Power Drive [Online]. URL: http://www.epri.com/epri_journal/jul_aug95/develop.html.

${ }^{8}$ Derrick, Anthony, Catherine Francis, Varis Bokalders, (1989). Solar Photovoltaic Products: A Guide for Development Workers. London: Intermediate Technology Publications, Ltd.

${ }^{9}$ Hansen, R. and Martin J., (1987). Photovoltaics for Rural Electrification in the Dominican Republic, Produced by Enersol Associates and the University of Lowell Foundation for the Department of Energy. Note: Cost ranges still accurate in 1998, based on author's experience
} 
powered icebox. Cooking in the Dominican Republic is accomplished by using either wood or locally made charcoal. Potable water can also be scarce in these areas since communities lack the energy resources to extract deep ground or spring water, relying instead upon surface sources that can be easily contaminated.

\section{Women's Participation in Energy Development}

A 1988 survey of work being done by various international donor agencies and non-governmental organizations (NGOs) to incorporate gender issues into energy projects, policies, and energy-related activities confirmed "women's special relationship with energy systems." The report goes on to assert that "women are important in energy planning because they manage the procurement and use of most energy resources in developing countries' household, agricultural, and small industrial subsectors," and finally chronicles "women as the group most affected by energy scarcity and related environmental degradation." 10

As evidence, in rural areas of developing countries, women spend proportionately more time than men engaged in survival activities such as firewood collection, water hauling, food processing, and cooking. In Latin America, $40 \%$ of rural women are affected by fuelwood scarcity and $45 \%$ are touched by water scarcity. Worldwide, the median time women and children spend collecting water is 1.6 hours per day in the dry season. This exertion of human energy goes largely "unmeasured, nonmonetized and unrecorded in energy statistics." 11

In most regions worldwide, females head $30 \%$ of households. ${ }^{12}$ In Latin America, women head $21 \%$ of households. The amount increases to $35 \%$ in the Caribbean. ${ }^{13}$ In Latin America about half of the femaleheaded households are located in rural areas. ${ }^{14}$ In these households and others, women are typically responsible for household fuel and food expenditures, often using revenue from their own incomegenerating activities to supplement household budgets. In rural areas, fuel may constitute $5 \%$ to $10 \%$ of non-food cash expenditures. ${ }^{15}$ As household managers, women also play a key role in influencing direct and indirect energy consumption. For example, women often monitor kerosene lamp use in order to prolong the fuel and cook during daylight hours in order to minimize night-time lighting needs.

To appreciate the complexity of the current energy situation in these rural areas, it is useful to visualize the range of typical activities requiring energy inputs and the source of such inputs. The matrix shown in Figure 1 analyzes the current energy situation in Latin America. The analysis can be used as a springboard for solutions that address both the component and comprehensive problems associated with energy scarcity in rural areas.

\footnotetext{
${ }^{10}$ Becherer Hanan, Jean, ed. (1988). Women and Energy: The International Network: Policies and Experience. Washington, D.C., The World Bank. 3.

${ }^{11}$ Reddy, 16.

12 Reddy.

${ }^{13}$ Cecelski, Elizabeth. (1998). Gender and Poverty Challenges in Scaling Up Rural Electricity Access. Paper for presentation at Village Power '98. Washington. DC.

${ }^{14}$ Waring, Marilyn. (1988). If Women Counted: A New Feminist Economics. San Francisco: Harper. 234.

${ }^{15}$ ibid. 18.
} 
Figure 1 illustrates how the energy inputs for daily household activities are heavily dependent on human energy and on polluting fuels. In addition, many activities considered vital to an improved quality of life such as refrigeration, are simply not feasible in unelectrified rural areas.

Since women are disproportionately responsible for household tasks, they, together with children, suffer high incidences of health-related problems associated with the use of traditional fuels for energy needs. For example, the open fire commonly used in Latin America for cooking in poorly ventilated indoor kitchens exposes women to high amounts of particulate pollution causing respiratory infections in children and chronic lung disease in non-smoking women. Indirectly, scarce fuel for proper cooking and water boiling can lead to malnutrition, diarrhea, and parasites. Safety is also a factor. Use of kerosene lighting has also been known to cause fires or burns, while women may search for firewood or water in dangerous locations and/or gather oversized wood or water loads. ${ }^{16}$

Energy issues can tend to get lost in the portfolio of development activities concentrating on urgent "basic needs." However, when the link between energy and basic needs like food and health can be made, energy becomes a complementary activity necessary to help women meet minimum quality of life levels. Several organizations, including Winrock International, Habitat for Humanity and Plan International, have made this link. As a result, international development organizations are paying greater attention to energy impacts, especially at the household level. Energy for cooking is a good example of this. Today, numerous indigenous and international groups are introducing alternative stove technologies, including ceramic, lorena (clay) and solar stoves. ${ }^{17}$

To illustrate how energy and basic human needs relate, consider the hierarchy of needs developed by the psychologist Abraham Maslow. Maslow argues that human needs can be arranged into categories ordered from the most to least pressing. At the base of they hierarchical pyramid are physiological needs, on which safety, social, esteem needs are built with self-actualization needs filling the pinnacle of the pyramid. Energy for clean water and lighting plays a role in helping people achieve the fundamental physiological and safety needs that are essential for one to ascend into fulfilling the psychological needs that enhance life. As such, development projects should view energy issues as an integral component of satisfying the range of human development needs. For example, it is well documented that education and income generation, two things that can be significantly enhanced with energy, can contribute to the sustainable fulfillment of basic needs, as well as the social and esteem needs associated individual and societal advancement.

The information in Figure 1 implies that community enhancement activities (such as education, health care, and religious gatherings) depend on day light hours or the use of kerosene lamps for nighttime use. In some cases, especially in the Dominican Republic, electric generators may be purchased or rotated to fulfill needs, although it is more common for these activities to remain in urban areas where energy resources allow for fuller utilization of facilities and equipment. As a result, rural populations are denied access to key services considered routine to their urban counterparts. The lack of these services, combined with limited opportunity for income-generation activities, is an oft-cited motivation for urban migration. Often men migrate to urban areas, either on a temporary or permanent basis, seeking opportunities that do not exist in rural areas, leaving women behind to cope with increased domestic and economic responsibilities.

\footnotetext{
${ }^{16}$ Reddy. 38.

${ }^{17}$ International organizations working in this area include Solar Cookers International, World Vision and Appropriate Technology International. Local organizations include ADEPE and FUDECO in the Dominican Republic and Proleña in Honduras.
} 
Figure 1: Traditional Fulfillment of Rural Energy Needs

\begin{tabular}{|c|c|c|c|c|c|c|c|}
\hline \multirow[t]{2}{*}{ Rural Energy Need } & \multicolumn{7}{|c|}{ Primary Source of Energy } \\
\hline & 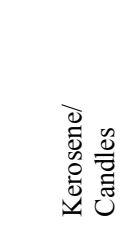 & 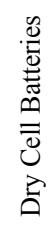 & 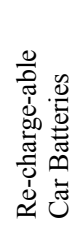 & 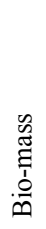 & 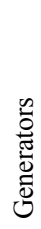 & 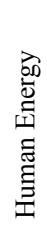 & $\begin{array}{l}\vec{d} \\
\mathscr{D} \\
\stackrel{0}{0} \\
\ddot{0}\end{array}$ \\
\hline \multicolumn{8}{|l|}{ Household } \\
\hline Lighting & $\diamond$ & & & & & & \\
\hline Cooking & & & & 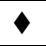 & & & \\
\hline Laundry & & & & & & $\boldsymbol{\nabla}$ & \\
\hline Radio/cassette & & $\vartheta$ & & & & & \\
\hline Television & & & $\diamond$ & & & & \\
\hline Fan & & & & & & & $\boldsymbol{\vartheta}$ \\
\hline Iron & & & & 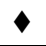 & & & $\diamond$ \\
\hline Refrigerator & & & & & & & 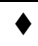 \\
\hline Water heating & & & & & & & $\diamond$ \\
\hline \multicolumn{8}{|l|}{ Community Enhancement } \\
\hline Potable water (pumping) & & & & & & 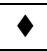 & \\
\hline Schools (lighting) & $\boldsymbol{\nabla}$ & & & & & & \\
\hline \multicolumn{8}{|l|}{ Health centers: } \\
\hline Lighting & 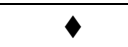 & & & & & & \\
\hline Vaccine refrigeration & & & & & 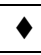 & & \\
\hline Hot water & & & & & & & 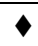 \\
\hline Community centers (lighting) & 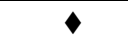 & & & & & & \\
\hline Street lighting & & & & & & & 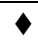 \\
\hline $\begin{array}{l}\text { Parks/protected areas } \\
\text { (communication radio, lighting) }\end{array}$ & $\vartheta$ & & & & 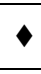 & & \\
\hline \multicolumn{8}{|l|}{$\begin{array}{l}\text { Income Generating/ } \\
\text { Microenterprises }\end{array}$} \\
\hline Carpentry & & & & & 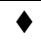 & & \\
\hline Laundry service & & & & & & $\diamond$ & \\
\hline Cafeteria/ice making & & & & & & & 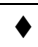 \\
\hline Telephone center & & & & & & & $\diamond$ \\
\hline Food processing & & & & & & $\diamond$ & \\
\hline Beauty salon & & & & & 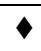 & & $\diamond$ \\
\hline Electronics repair & & & & & & & $\diamond$ \\
\hline Seamstress/tailor & & & & & & 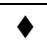 & \\
\hline Bakery & & & & $\diamond$ & & & \\
\hline \multicolumn{8}{|l|}{ Agriculture } \\
\hline $\begin{array}{l}\text { Water pumping for } \\
\text { livestock/irrigation }\end{array}$ & & & & & $\diamond$ & & $\diamond$ \\
\hline
\end{tabular}

Source: Adapted by the author from the Global Transition Group matrix illustrated in Figure 2. 
Clearly the links between women and energy are compelling in the context of the current energy reality of developing countries. It is imprudent to generalize too broadly the characteristics of this relationship since each culture, and indeed each domestic situation, has been touched by a unique blend of social, economic, political, technical and environmental influences. Nonetheless, there is sufficient anecdotal and empirical evidence to affirm women's important energy role and, in turn, demand that projects seeking to affect grassroots energy improvements involve women in a deliberate and participatory fashion.

\section{Decentralized Power: A Solution for Rural Energy Needs}

In much the same way that mainframes have given way to personal computers and hardwired telephone systems have moved towards wireless cellular phones, the energy sector may find that part of the answer to the social, economic, and political pressures for rural electrification lies in decentralized energy systems. Decentralization simply implies that energy is generated and supplied directly at the end use location eliminating the need for distribution and transmission infrastructure. Decentralized energy systems are often discussed within the context of renewable energy technologies because these technologies can take advantage of readily available local resources (sun, wind, water) to generate the necessary energy.

Decentralized renewable energy systems are unique in that they can generally target a particular energy need, be mobilized relatively quickly, be individually or communally obtained and are environmentally sound. These systems also keep the energy system close to the end user, allowing the end user to influence design, placement and consumption.

The Global Transition Group ${ }^{18}$ developed the decentralized energy matrix shown in Figure 2 based on its experiences in Latin America. Figure 2 couples rural energy needs with feasible decentralized technology that can be applied in rural areas of developing countries as a marked improvement over the traditional energy sources previously discussed and illustrated in Figure 1.

The Figure 2 matrix is just one conceptualization of how technology may be molded and adapted to meet local needs. It is a model that embraces decentralized energy supply, and, even more specifically, decentralized renewable energy supply, as a sustainable option for some of the most remote and needy areas of the world.

While several organizations and companies ${ }^{19}$ have made decentralized rural energy their primary mission, no one organizational, entrepreneurial, or community effort any where in the world has executed the full range of technology options in order to meet the specific energy needs of any given community. Indeed, this is not the intent. Instead, the matrix has been presented as a menu of options designed to provoke solutions that consider energy not as one generic need but rather as a need with diverse component parts; components, which when met, can be the means to improved human development activities. The matrix is powerful in its ability to match appropriate technologies to real needs. The matrix is also valuable because it helps the practitioner resist the temptation to view each country or community as an indistinct entity

\footnotetext{
${ }^{18}$ The Global Transition Group consists of Enersol Associates, Inc., a non-profit development organizations, Soluz Inc., a commercial energy services company and Global Transition Consulting, a company jointly owned by Enersol and Soluz. All three entities have extensive practical experience in implementing rural electrification projects in developing countries.

${ }^{19}$ Nonprofit organizations focusing on decentralized renewable energy include: The Solar Electric Light Fund (SELF), Winrock International's Renewable Energy and the Environment division, and Solar Energy International. Companies involved in decentralized renewable energy include Soluz, Inc., SELCO, and Sunlight Power International
} 
with standard needs - a common practice among development projects designed to reflect developed, industrialized countries" definition of "need."

The matrixes in Figure 1 and Figure 2 can, and should, be adapted to each situation encountered. Furthermore, the adaptation should be a participatory event with community members, especially women, so that the nature and ranking of the needs is understood by those seeking to match technologies with applications. Proposed technological solutions should also be prioritized and examined in a participatory fashion. In doing so, it is useful to think of energy not as the goal, but rather a means to reach the goal. It is comparable to the classic marketing axiom that "the importance of physical products lies not so much in owning them as in obtaining the services they render. We buy a car because it supplies transportation service. We buy a microwave oven because it supplies a cooking service. Thus physical products are really vehicles that deliver services to us. ${ }^{20}$ In thinking of energy as a product which delivers a service a health service provided as a result of the clean water or nonpolluting lighting solar lighting or cooking services from kerosene or liquid petroleum gas - it becomes clear that the energy is a facilitator of solutions to complex and multi-faceted human development challenges. It also becomes clear that decentralized energy solutions help to keep energy decision-making at the local level.

Decentralized energy systems hold greater opportunity for women's involvement when compared to conventional energy delivery mechanisms. For example, decentralization pushes decision-making to the local level where women are far more likely to be involved, often simply due to mere proximity - women are in or near the home much of the day. Women also tend to exercise more decision-making control by rationing or increasing loads depending on the present activity or energy situation. Decisions related to system upkeep and energy distribution for entertainment purposes may be balanced with other family members. The end result is a relational connection to energy - an opportunity women in particular rarely have in the world's conventional utility sector.

In contrast, decisions associated with conventional, utility-centered energy models are made at the point of generation, transmission, or distribution by professionals with limited knowledge of the broad implication of the product's end use. An example of this is the diversion of electricity and water for tourist areas. The diversion is a political and economic decision made within utility companies that often is to the detriment of rural household and communities located out of range of the tourist facilities.

${ }^{20}$ Kotler, Philip (1997). Marketing Management: Analysis, Planning, Implementation, and Control. Upper Saddle River, NJ: Prentice-Hall, Inc. 10. 
Figure 2. Matching Energy Technology and Rural Need (Dispersed Population)

\begin{tabular}{|c|c|c|c|c|c|c|}
\hline \multirow[t]{2}{*}{ Rural Energy Need } & \multicolumn{6}{|c|}{ Energy Source } \\
\hline & 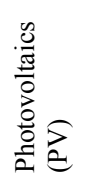 & $\vec{z}$ & 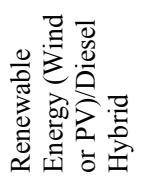 & 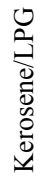 & $\begin{array}{l}\mathscr{n} \\
\tilde{\Xi} \\
\tilde{\Xi} \\
0 \\
0\end{array}$ & 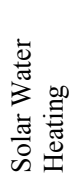 \\
\hline \multicolumn{7}{|l|}{ Household } \\
\hline Lighting & $\diamond$ & $\diamond$ & & & & \\
\hline Radio/cassette & 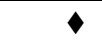 & $\diamond$ & & & & \\
\hline Television & 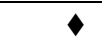 & $\diamond$ & & & & \\
\hline Fan & 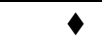 & $\diamond$ & & & & \\
\hline Iron & & & & $\diamond$ & & \\
\hline Refrigerator & $\diamond$ & $\diamond$ & & $\diamond$ & & \\
\hline Cooking & & & & $\diamond$ & $\bullet$ & \\
\hline Water heating & & & & & $\diamond$ & 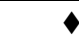 \\
\hline \multicolumn{7}{|l|}{ Community Enhancement } \\
\hline Potable water (pumping) & 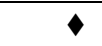 & $\diamond$ & & & & \\
\hline $\begin{array}{l}\text { Schools (audio-visual, computers, } \\
\text { lighting) }\end{array}$ & $\bullet$ & $\bullet$ & & & & \\
\hline \multicolumn{7}{|l|}{ Health centers: } \\
\hline Lighting & $\diamond$ & $\diamond$ & & & & \\
\hline Vaccine refrigeration & 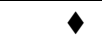 & $\diamond$ & & & & \\
\hline Hot water & & & & & & $\bullet$ \\
\hline $\begin{array}{l}\text { Community centers (lighting, } \\
\text { PA/music system) }\end{array}$ & $\diamond$ & $\diamond$ & & & & \\
\hline Street lighting & & $\diamond$ & & & & \\
\hline $\begin{array}{l}\text { Parks/protected areas } \\
\text { (communication radio, lighting) }\end{array}$ & $\bullet$ & $\bullet$ & & & & \\
\hline \multicolumn{7}{|l|}{$\begin{array}{l}\text { Income generating/ } \\
\text { Microenterprises }\end{array}$} \\
\hline Carpentry & & & $\diamond$ & & & \\
\hline Laundry service & & & $\bullet$ & & & \\
\hline Cafeteria/ice making & & & $\diamond$ & & & \\
\hline Telephone center & & & $\diamond$ & & & \\
\hline Food processing & & & 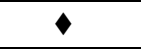 & & & \\
\hline Beauty salon & & & $\diamond$ & & & $\checkmark$ \\
\hline Electronics repair & & & $\diamond$ & & & \\
\hline Seamstress/tailor & & & $\bullet$ & & & \\
\hline Bakery & & & $\diamond$ & & & \\
\hline \multicolumn{7}{|l|}{ Agriculture } \\
\hline $\begin{array}{l}\text { Water pumping for } \\
\text { livestock/irrigation }\end{array}$ & $\bullet$ & $\diamond$ & & & & \\
\hline
\end{tabular}

Source: Global Transition Group, Chelmsford, MA, 1997. 


\section{Solar-Based Rural Electrification: A Case Study}

Perhaps one of the best known applications of decentralized renewable energy rests in a model developed by Enersol Associates, Inc., a U.S.-based, nonprofit international development organization founded in 1984 to improve the quality of life in rural areas of developing countries by fostering the use of solar

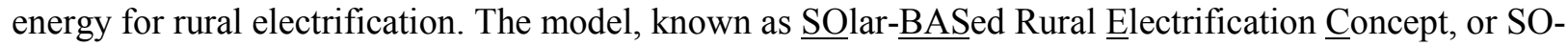
BASEC for short, initially focused on disseminating residential photovoltaic (or solar-electric) systems to rural households in the Dominican Republic ${ }^{21}$ via local market and institutional mechanisms. In 1992, Enersol extended its programs into Honduras, Central America, where the energy situation closely mirrored that of the Dominican Republic. The model has been expanded over the past decade to encompass energy needs beyond residential electricity.

The SO-BASEC model has been highly regarded for its ability to link rural communities with sustainable energy technology through its emphasis on two key components:

(1) Micro Enterprise Development: Enersol provides technical assistance and training to establish microenterprises as a local technology delivery network, and Access to Credit: Enersol makes available nontraditional financing arrangements that are attainable by rural populations.

The interaction of these components ensures that local knowledge is nurtured and built upon and that the technology distribution and acquisition is accomplished within a market mechanism that reinforces ownership and leverages resources. In recognizing the role of women in rural life, Enersol is keenly conscious of women's power to affect the technology's acceptance. While Enersol's work can not be deemed a "women in energy" project, neither can it be classified as a "men in energy" project. The SOBASEC model is an energy project that seeks to incorporate the needs and strengths of both men and women, poor, middle-class and affluent, skilled and unskilled into an energy paradigm that serves their individual and unique requirements. It is distinguished by its record of leveraging the strengths and knowledge of diverse sectors of the society, including micro-entrepreneurs, nonprofit organizations, international importers and government officials. Enersol's work has resulted in the installation of new photovoltaic systems at an average annual growth rate of nearly $85 \%$ in Honduras and $65 \%$ in the Dominican Republic. More specifically, in Enersol's first year of activity in Honduras 50 systems were installed. By the end of 1998, over 2000 systems have been installed. In the Dominican Republic, 25 systems were installed in 1986, growing to over six thousand today.

Enersol's inclusion of women at all project stages has been an evolutionary process. While much of the focus on women was deliberate from the outset, Enersol acknowledges that internal as well as external influences have impacted the model's development and, correspondingly, its results when it comes to gender issues. The following section describes some of the SO-BASEC model's core components and applications. Each subsection concludes with an explanation of how women and gender issues have been incorporated and the obstacles and opportunities encountered by a gender focus.

\footnotetext{
${ }^{21}$ As one of two countries sharing the West Indies Caribbean island of Hispaniola, the Dominican Republic has a population exceeding seven million. Forty percent of Dominicans live in rural regions of the country where agricultural pursuits often complement limited income received from family members in urban areas or abroad. Seventy percent of rural Dominican families, an estimated 2 million people, live beyond the reach of the centralized utility's grid.
} 


\section{Microenterprise Development}

\section{Using the Market}

The SO-BASEC model is rooted in the belief that the private sector, specifically micro-enterprise, is a natural choice as an agent to install and maintain decentralized energy systems. Enersol bases this assertion on evidence from other solar electrification projects where NGOs have used grants to install photovoltaic systems. In many of these cases, there was inadequate follow-up after the initial installation due to insufficient funds or changing organizational priorities. Some government projects have also failed when heavy subsidies contributed to impressive distribution but systems later fell into disrepair caused by the end users' lack of funds and knowledge for minimal technical upkeep, including the replacement of the battery ever 1 to 1.5 years. In both instances, malfunctioning systems severely damage the reputation and potential of the technology. Additionally, subsidized projects reach only a predetermined population, leaving others to acquire the technology through an underdeveloped supply chain. Not unexpectedly, the final cost of PV systems obtained outside of subsidized projects seems unreasonably high by comparison, so people often prefer to wait for the next program rather than proactively resolve their own energy problems. The possibility of this "next (subsidized) program" becomes increasingly elusive as concessional financing from multilateral and bilateral aid organizations to pay for the growing power production and delivery needs of developing countries declines, leaving private capital to play a more prominent role. Therefore, full-cost recovery must be demonstrated in order to attract private capital. ${ }^{22}$

Proving the feasibility of full-cost recovery has been the cornerstone of Enersol's photovoltaic work. Its development of a network of microenterprises that can locally purchase equipment and promote the technology throughout rural regions helps to balance both accessibility and affordability for rural end users. Furthermore, micro enterprises dedicated to this line of business have a financial incentive to respond to maintenance needs in order to preserve both the business and technology's reputations (and in turn attract more customers).

Enersol has dedicated much of its efforts to developing a base of microenterprises versed in both the technical and business aspects of entrepreneurial energy ventures. Its approach has been to identify capable men and women who may or may not have previous business experience but who already are based in or near a rural area and involve them in training activities. In turn, a solid knowledge base and a social support network are formed. Enersol, together with its local non-profit counterpart organizations, ADESOL in the Dominican Republic and ADESOL-Honduras in Honduras, have designed a training program that emphasizes practical, hands-on instruction over a series of five-day progressive and reiterative courses.

Successful completion of each course is rewarded with recognition as a certified technician. Such certification is important as private financing institutions seek qualified technicians as part of an applicant's appeal for financing. To compliment the training components, the SO-BASEC model places emphasis on follow-up visits and assistance, designed to offer more one-on-one support. In this way, system quality and business success can be evaluated within the small business' local context.

To offer peer support, SO-BASEC encourages the formation of a network of trained technicians providing photovoltaic services. The network allows for greater cohesiveness and exchange of ideas among small businesses working in different regions of the country. In the Dominican Republic, this network has used its collective strength to confront political policies affecting their businesses and has

\footnotetext{
${ }^{22}$ Covell, Philip W., and Hansen, Richard D. (1995). Full Cost Recovery in Photovoltaic Projects: Debunking the Myths about PV Equipment Subsidization. Enersol Associates.
} 
been able to exchange information about system component quality, such as the quality of locally manufactured batteries and bulbs.

\section{Gender Perspective}

The use of microenterprises to reach rural households with decentralized energy systems makes it important that: (1) women have the opportunity to participate as micro-entrepreneurs, and (2) all microentrepreneurs are trained to work with women as clients and end users of PV systems since women are the primary household energy users and, as such, must be involved with system design and maintenance instruction.

Of the approximately 30 active businesses currently developed with Enersol support, two have women in significant leadership positions and one relies on a female technician for system installation and maintenance. Unfortunately, these numbers fail to reflect the concerted effort Enersol has made to recruit women at all stages of microenterprise development. A closer review of the efforts to date and future opportunities is useful in revealing the challenges associated with selecting, training and reinforcing women as solar energy entrepreneurs.

Selection Stage: Enersol's typical recruitment process begins with the selection process. Candidates for training are typically chosen from a pool identified by collaborating development practitioners (i.e., other local NGOs, Peace Corps volunteers, etc.) and existing microenterprises. In some cases, the candidate learns of Enersol's program and makes his or her interest known. Generally those selected through this informal process have been men. The roots of this rest, at least in part, on prevailing preconceptions in both developing and developed countries of electrical professions as "man's work." Additionally, those charged with identifying candidates have been mostly men. While this does not mean that the men automatically discriminate against women, the fact remains that in the countries where Enersol works, deep cultural taboos against excessive socialization between women and men, especially men unknown to the woman or professional men, persist. Therefore, it is difficult for the men responsible for selecting candidates to ascertain a woman's interest in and/or capability for developing a technically oriented microenterprise, therefore effectively precluding women from the selection process.

It would logically follow that as Enersol engages more women in the selection process, more women will be recruited for training. In 1993, Enersol did begin to place more women, primarily staff members and collaborators, in candidate recruitment positions. From 1985 to 1995, records shows that $27 \%$ of the candidates Enersol trained in professional courses" were women. However, during the same period, only $9 \%$ of the candidates participating in technical, micro-enterprise preparatory courses were women. It is unclear whether these low percentages, especially in the latter category of training courses, are due to the inability of Enersol to identify women for the courses or to women being selected, but declining to participate in later phases due to cultural, economic or other barriers.

Training Phase: After being identified and selected, a candidate enters a training phase. This phase is comprised of two to three one-week courses over a two-year period with periodic refresher meetings. The courses are held at modest training centers with dormitory facilities in or near rural areas. Enersol has heralded the overnight aspect of training for the opportunity it gives participants to interact with trainers and other trainees to reinforce friendships and training material. While recruiting women is a formidable problem, getting women to attend the training workshops poses an equally challenging task, since in Honduras and the Dominican Republic, like many other developing countries, women have been reluctant

\footnotetext{
* Professional courses are designed to orient NGO representatives to the fundamentals of solar energy and how solar energy finance funds can be designed to support micro-enterprise installations and compliment other development activities with an NGO portfolio.
} 
to travel alone to a one-week training environment which will require cohabitation with men. In some cases, family responsibilities prevent such a time commitment; in others social mores directly forbid the endeavor.

Enersol's technical training courses have ranged from $0 \%$ to $30 \%$ female participation. In total, 20 females have completed at least one level of technical microenterprise training. Five of these women have progressed to, and elected to participate in, advanced courses. When women have participated in the training special housing arrangements have been made to segregate men and women. In the Dominican Republic, the housing for women is located approximately 20 minutes away from the training center and from male dormitories, providing sufficient privacy for the women trainees but also sacrificing interactive time with other trainees and trainers.

Enersol is currently in the process of constructing a new training center in the Dominican Republic that will provide for adjacent but segregated dormitories so that both men and women can fully partake in course activities. In addition to technical training, Enersol experimented with an all-female professional training course in October 1993 with funding secured from the U.S. Agency for International Development's Office of Women in Development. Enersol recruited both micro-enterprise candidates and representatives from indigenous NGOs interested in developing decentralized photovoltaic activities in their region. The training was successful in terms of trainee cohesiveness and level of participation - each woman fully participated in the installation of an actual solar-electric system. However, no micro entrepreneur dedicated to marketing and installing photovoltaic systems emerged from the group of ten. However, one NGO representative did go on to play a significant role in her NGO's solar project. Enersol has elected not to undertake additional women-only training, partially due to limited funding and partially due to an increased emphasis on community-centered activities which involves women in other ways, discussed later in this paper.

Reinforcement Stage: After training, technicians return to their home area to undertake the arduous task of establishing a viable PV microenterprise. This is generally a slow process with trainees translating their new knowledge into an actual PV system installation for a neighbor. The effort it takes for a trainee to transform him or herself into a micro enterprise varies by person and situation, but it always involves marketing, a small capital inflow, and time. Enersol and its counterpart organizations have been conscientious of supporting start-up microenterprises during this critical phase by visiting them often and assisting with promotional, accounting, and technical issues. For the women that have been selected and successfully completed training, this phase offers yet more unique challenges. Here again, family commitments and social norms may restrict time with and access to clients. In some countries, lack of access to transportation may severely limit the mobility necessary to obtain system parts and service a territory sufficiently large enough to realize an economic return. Private transportation, like cars and motorcycles, are typically the property of male family members in Enersol's program countries. Womenled microenterprises also face challenges from end users, both men and women, who may question a woman's ability to manage a business or undertake a technical task. In the Dominican Republic, Enersol's counterpart organization, ADESOL, has instituted a qualification program whereby qualified PV micro entrepreneurs are awarded an identification card certifying the entrepreneurs' credentials and affiliation with ADESOL. This system has helped both male and female entrepreneurs demonstrate their credibility and skills to potential clients.

Enersol's effort to involve women at the microenterprise level has been a difficult one. As illustrated, social norms and preconceived notions have had to be confronted at every turn. Despite these, the effort has been relatively successful in that women have ascended to various levels within microenterprises. (See the sidebar "Profile of A Solar Entrepreneur - One Woman's Story"). Success, however, is a relative term and there is little with which to compare Enersol's experience either within or beyond the energy field. Most microenterprise projects have focused on traditional cottage-industry level businesses, with 
women working in conventional activities in or very near their homes. Enersol's model has allowed women to be pioneers in an emerging field that is outside the traditional realm. The skills they gain can be utilized within their immediate community or expanded into the surrounding area. There is more to do, but Enersol's experience provides an adaptable model that serve as a foundation.

\section{Access to Credit}

Establishing a network to deliver decentralized energy systems is only one side of Enersol's model. A delivery network's impact is limited if only a small percentage of rural families and communities can purchase the systems. Enersol was aware that a photovoltaic delivery system could not be established within a financing vacuum. In response Enersol created a mechanism capable of redirecting the US $\$ 11.00$ to $\$ 46.00$ expensed monthly by Dominicans for traditional energy resources energy into monthly payments on a PV system. The PV system displaces the need for batteries, kerosene, and other crude energy devices and the redirects their costs into monthly finance installments.

Enersol's SO-BASEC model relies on already established local NGOs to offer and manage consumer credit funds, primarily capitalized by donated funds. A local NGO has the advantage of already being established and respected in the targeted rural area. Additionally, NGOs have an established administrative base, and the SO-BASEC approach complements other existing community development activities. The availability of funding for PV system purchases allows the NGO to encourage microenterprise development - both solar microenterprises acting as system suppliers and beneficiaries of systems who may use solar power to initiate or enhance income-generating activities.

Loans are issued directly to end users who repay the capital, plus interest set near prevailing commercial rates, for a one- to three-year period. The system serves as collateral until the loans are paid off. Figure 3 illustrates how the loan funds and microenterprises work together to deliver accessible and affordable systems to end users.

Figure 3: Enersol's Solar-Based Rural Electrification Model

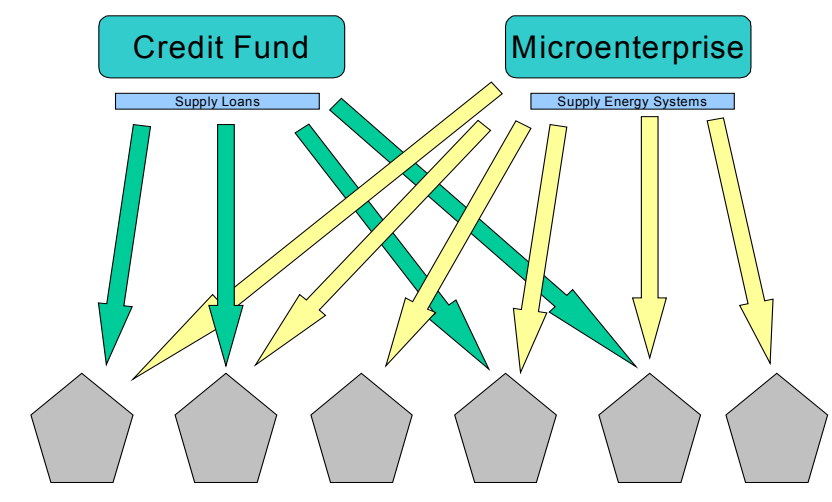
Note: Not all households acquiring PV systems have access to financing; some pay cash and therefore deal

Source: Solar Electricity for Rural Development, Brochure, Enersol Associates, Inc. 


\section{Gender Perspective}

Significant progress has been made in recognizing and documenting the distribution of credit to women over the past decade. The Microcredit Summit convened in Washington, DC in February of 1997 is one of the most visible examples of efforts being made to focus the world's attention on the importance of microcredit in development. The Summit launched a worldwide campaign to reach 100 million of the world's poorest families, especially the women of those families, with credit for self-employment and other financial and business services by 2005. International and local efforts in this arena confirm that, while women are often constrained by a lack of traditional assets and socio-economic factors, these same women find unique and creative ways to economically support their families. However, these ways are generally on a different and smaller scale than their male counterparts leading them to be ignored by many traditional lending institutions. Poor literacy rates, little or no professional education, limited mobility to reach financial institutions and borrowing inexperience have penalized Dominican and Honduran women in need of finance capital.

Enersol's projects are unique in helping these women bridge the gap between no access credit and access to credit. The energy systems that Enersol finances are generally household systems, which women directly benefit from and control. As such, women, when given the opportunity, have a special interest in arranging credit that allows for the acquisition of an energy system that will improve the quality of life for her and her family. It is well documented that women tend to use additional income for food, school fees, clothes and other households needs. Women also have a distinguished repayment record ranging from 90 to $100 \%$ in micro-credit programs. ${ }^{23}$ In addition, loans for PV systems do not require that women demonstrate large asset holdings. Instead, the solar panel itself acts as collateral over the loan life. The funds used to make regular payments are usually redirected from expenditures women are already making for traditional energy. Finally, the local NGO administration of the loan funds means that the lender and borrower are generally already acquainted, thus resulting in a more comfortable and less risky environment for both parties.

Receiving financing for a solar energy system can be a first step to acquainting a woman with financing opportunities. Enersol has seen the confidence women gain by being responsible for the system's payment and the accomplishment exuded by women who ultimately achieve full ownership of the system at loan end. Cecilia Martínez of Arroyo Seco in the Dominican Republic, for example, enthusiastically demonstrates her fully paid PV system to local and international visitors. Helping women transition into borrowers requires a directed education campaign to those responsible for identifying and qualifying loan candidates. Therefore, as part of its micro-enterprise training courses and technical assistance to NGOs, Enersol emphasizes the importance of recognizing women as borrowers. The consciousness-raising campaign has been successful with women representing approximately 33\% of loan recipients since 1996 in the Dominican Republic, according to Enersol's counterpart, ADESOL.

\section{Applying SO-BASEC to a Range of Energy Needs}

As Figure 2 shows, numerous other decentralized renewable energy technologies can be deployed to meet rural household and community energy needs. Enersol's SO-BASEC model, as discussed to this point, has focused primarily on using photovoltaic technology to meet electricity needs for lighting, entertainment, and small appliances for homes, businesses, and community centers. This was Enersol's primary focus in its early years. However, beginning in 1994, Enersol began to address other energy needs in the Dominican Republic and to adapt the model accordingly. The subsequent focus on other technologies and needs within Figure 2 attests to the flexibility of both Enersol's model and decentralized

\footnotetext{
${ }^{23}$ Cecelski.
} 
energy. In the early stages, the bulk of the organization's energies were spent on building the local capability to deliver, service, and finance PV systems. The time commitment was also essential for people to become familiar with and trust the new technology. These factors combined to encourage a pull, rather than push, dissemination mechanism.

Enersol's has expanded into using PV and wind energy to pump potable water and manage designated park and buffer zones (by powering communication systems and electrifying guard and research stations), as well as exploring alternative cookstove designs. Its expansion has been accomplished by maximizing the model's components - namely market-driven delivery combined with access to funding.

The installation of community water systems is a prime example. The water systems, powered by either PV or wind energy technology, differ from stand-alone PV system in that they are community-owned and managed. Introducing community elements into financing arrangements requires a heightened need for the coordination of payments from several beneficiaries as opposed to the single family borrower present in Enersol's photovoltaic credit schemes. Nonetheless, Enersol has been able to forge an adapted SOBASEC model that continues to depends on qualified commercial technicians to install systems and NGOs to finance the communities' costs, typically over a five-year time period. Training has also been expanded to involve community members so that they can better understand their unique role within the procurement, installation and maintenance process.

\section{Gender Perspective}

Enersol has found that women in the Dominican Republic play an even greater role in the procurement, installation and upkeep of decentralized energy for water pumping than they do with household PV systems. This may be attributed to the fact that the water obtained from these systems is principally used for household chores like cooking and washing. In addition, the availability of a reliable and clean water source becomes a time saver for women, allowing them to diversify their activities. Enersol staff have observed women emerge as the natural leaders of community water associations and take assertive action in approaching NGOs and microenterprises to find out how to acquire such systems. Evidence also indicates that women, more often than not, take key responsibility for enforcing the proper use of the water system and ensuring that all community members make finance payments. A breakdown in proper use or payment schedules would result in diminished water availability, and by extension, a diminished quality of life for women. It appears that women understand this and strive to unite the community to comply with the systems' technical and economic parameters. 


\section{Conclusions and Lessons Learned}

Enersol's work to build solid foundations has depicted one model for the dissemination of decentralized renewable energy. Although not focused exclusively on women in energy, Enersol's inclusion of women at varying levels in all project stages helps to demonstrate many of the opportunities and obstacles an organization faces in managing a gender-integrated project.

It is appropriate to conclude with some key influences that have helped Enersol better achieve its mission.

\section{Staffing}

Enersol's awareness of women as project participants and beneficiaries is at least partially derived from the fact Enersol's staff is half women professionals. In its headquarters, three of the four staff members are women, one of which has extensive international living and work experience. In addition, Enersol's lead engineer, who travels between field offices, is a woman. The bulk of Enersol's field work is conducted by Enersol's counterpart organizations. Women also heavily staff these, including the Executive Director and President of ADESOL-Honduras (different people) and one of four full-time professionals of ADESOL-Dominican Republic. Enersol's commitment to female input goes to the Board of Director level with $20 \%$ of Enersol, $20 \%$ of ADESOL-Dominican Republic and $50 \%$ of ADESOLHonduras' boards comprised of women.

\section{Funding}

Some of Enersol's efforts have either been catalyzed or supported by external funding sources. Early funding restricted to financing PV systems for women from New England Biolabs, for example, helped Enersol put into place mechanisms for identifying financial mechanisms capable of identifying female loan recipients and tracking their progress. As already mentioned, Enersol also received funding to experiment with a women's training course. The curriculum from that training has been modified and used in numerous subsequent courses. To a lesser extent, multi- and bilateral funding from the United Nations Development Programme and AID mandating gender-specific content in the proposal and reporting phases of awards have held Enersol and other organizations accountable to equal treatment of the genders.

The importance of recognizing women as not only users of energy in rural areas of developing countries, but also procurers of energy is fundamental to developing energy projects that can successfully meet both gender's needs. The inclusion of women becomes even more crucial when shifting to a decentralized model of energy distribution since matching renewable technologies and financing to actual user needs requires interaction with the full community. Decentralization is unique in its ability to meet every household's and communities' needs at a pace and in a manner shaped to its particular requirements. Decentralized energy service is also valued for its inherent linkage to end user decision making regarding procurement, design, installation, maintenance, and consumption.

When matching decentralization with a model like Enersol's which is sensitive to local customs and culture, the opportunities communities to obtain and sustain energy systems expands. Enersol's model has been able to build the delivery and financing networks necessary for families and communities and the men and women who make them up to be more proactive in meeting their energy needs. 


\section{Side Bar \\ Profile of a Solar Entrepreneur: One Woman's Story}

Marina Reyes de Alfaro (MR) was the one of the first micro entrepreneurs trained by Enersol in Honduras in 1992. Marina helped introduce photovoltaic energy in the northwestern part of the country while being based in her hometown of Santa Barbara. The following is her story as told to Philip Covell (PC), Executive Director of Enersol in June of 1988. (translated from Spanish)

PC: How many women in Santa Barbara work in agriculture?

MR: Very many, perhaps 30 of every 100 women.

PC: What do they do?

MR: They prune, prepare and fertilize coffee plants. Some fumigate the crops. Others have small gardens, growing radishes, corn, or beans, but in Santa Barbara, its coffee that makes the world go around.

\section{PC: What is your link to agriculture?}

MR: I have helped with the coffee, mostly in the seedbeds. I know how much distance to leave between the plants and how to manage the insecticide. Harvesting is difficult, but I have done it. I really prefer buying and selling. I had a pulperia (small general store), and I bought coffee from neighbors by the can (50 to 130 pounds/can) and sold them wholesale through the pulperia.

PC: What was your first impression of a solar photovoltaic panel?

MR: The first thing I saw was the panel alone, and I didn't think there was much hope of that doing anything special. I asked myself 'Who are these Americans, what are they thinking?' When Richard* began to ask about our lighting situation, he observed that I had a [car] battery. He said "you can use this [a 20 watt solar panel] to charge that battery." The battery was a gift, but it was very large. It always lost its charge and had to be recharged in town. Once when I connected the battery it burned out a radio. I later learned that it this was because we connected a 9-volt radio to the 12 -volt battery.

Richard and I got out a screwdriver and took out one of the cells so that the battery was only 8 volts and we could use the radio. We also tried an 8-watt florescent bulb. We connected the panel to the radio and the radio turned on; then we shaded some of the solar cells and it stopped playing. The price was 3000 Lempiras [US\$600] which was too much for me to buy with cash, but he left it with me as a demonstration panel. I read all the information.

PC: What did you do with the PV panel?

MR: I ended up using the solar system for the pulperia. This is how it happened: Marcos [Mark Johnson, a Peace Corps volunteer] had talked with Richard and one day arrived with a note that asked if I would agree to install the system. I talked with my mom who told me not to put on airs. She said, "think about it hard." One day Patricia [Mark’s wife] arrived in Santa Barbara and started asking

\footnotetext{
* Richard Hansen, President of Enersol Associates and Phil Covell first introduced Marina to solar energy during a visit to Honduras in 1991 to determine the feasibility of extending the SO-BASEC model to Central America.
} 
around for me. By coincidence she talked with my dad. When my father said that I was his daughter, she hugged him and said "take this note to Marina. We are going to install the solar system this Saturday." When my father arrived at the house, he was very serious, like he had bad news. "A gringa sent you a note," he said. That was a Monday. On Saturday, June 23, 1991, they arrived to install the system.

That night we turned on the lights for the first time. Everyone stopped and asked, "How did light get here?" All of a sudden I had a list of 55 interested people. After having my kids, this is the most special thing in my life. After that people stopped to take photographs; people visited from Guatemala; there were interviews. Juanito [John Rogers, another Peace Corps volunteer] brought an American with a video camera. The ODEF (Organization for Women's Business Development) of Honduras came to see it. When Juanito arrived, he brought a blender and the next time people from ODEF came I made them fruit milkshakes. With Juanito we fixed the tape recorder. The people around the area, mostly farmhands passed by at night. Later we put in the lottery thanks to the light. I was 23 years old.

PC: When you began installing systems, most of the solar technicians are men. How was it being a woman in this business?

MR: With so many people asking how to buy a PV system, I simply saw the business possibilities. I did installations with Juanito. I would make the sale and Juanito would help me install the PV system. The first installation after the demonstration was for a lawyer. He was impressed. He asked me if I liked to make tortillas. However, no one seemed opposed to me selling and installing systems.

PC: What were your impressions of the business and market?

MR: I started the business ${ }^{*}$ in 1992, eight months after installing the demonstration system in Santa Barbara when I saw the demand. The people thought I was very serious. I liked the clients. I found Angela [Angela Garay, an ODEF extensionist], and we shared the same office. Richard was surprised when I called him and told him I had a telephone in Santa Barbara. I called it Industria Electrica Bella Vista de Santa Barbara. I had a checkbook and everything.

I began to import solar equipment from the U.S. We moved the office to San Pedro Sula at the end of 1993. The clients had to go to San Pedro anyway in order to acquire other accessories and I believed that it was the future. I left Santa Barbara and the pulperia. Mom took care of it during the day. Richard talked with mom about the decision. He said that I had spark. Mom said, "I don't know, what do you think?" I still go home every Saturday and Mom still has the pulperia, but I really don't know much about its daily business anymore. Now I ask, "what are the prices?" We closed the house, packed everything and moved to San Pedro Sula. We opened there on February 1, 1994. We opened a bank account. It all happened pretty fast.

PC: What have been the biggest obstacles in the business?

MR: I haven't had any! Well, when there isn't any product, like PV panels. Imagine, so many people wanting panels, with money in hand. At times, I have been demoralized because I can't always serve the clients.

\footnotetext{
* Marina became the head the Honduran subsidiary of Soluz, Inc: a US-based company with another subsidiary, Industria Electrica Bella Vista, in the Dominican Republic. Soluz has been internationally recognized for its Solar Electric Energy Delivery ${ }^{\top M}$ (SEED) program, whereby clients lease rather than purchase or finance a PV system.
} 


\section{PC: What about your family?}

MR: I married Samuel before we moved to San Pedro Sula. Then we were robbed, so Samuel began to install PV systems. He got involved in what I was doing. He is a coffee grower, solar installer and now he has a new farm. He has cows that he got in exchange for installing a system. My first child, Darold, was born on September 19, 1995.

PC: Now that you live in the city, San Pedro, do you miss the rural areas?

MR: Yes (laughter). I would like to be there. There is a lot of pressure here in San Pedro Sula - assaults and robberies. Back there it is more tranquil. But in Santa Barbara there are not good schools for the kids. I miss things like tortillas. I have a friend here who makes tortillas like we used to make them at home.

PC: What do you think of the investments being made in the business?

MR: As a businesswoman, I love it. I can see the goal. I understand that all of the effort we make is necessary. At times, I felt like it wasn't going anywhere. But I can see that it is bearing fruit will grow more. We are internationally recognized.

There are not words to tell you the happiness I feel. When financiers come, I realize the commitment we have to make. We have to meet our goals. We have work ahead of us. I can not leave for Santa Barbara whenever I want. I have a commitment here and the desire to keep working.

PC: What has been the impact of solar photovoltaic energy?

MR: It is nice when you see a farmer/rural dweller that has lived with candles and now has a solar energy system. When I put the demonstration system in my house, people noticed that I had light in the house. The most interested were women. The demonstration system left a good impression on the women.

The women get up at 3 am during the harvest season because they have to cook everyone's food. A light bulb powered by solar energy lights up the whole kitchen. It is much easier to light and it makes it easier to work. With kerosene gas, sometimes the tortillas have a gas flavor, and some people have had accidents with the kerosene lamps.

Solar energy also helps for night studying. The candles and lamps were smoky. You have to work directly on top of the lamp to see.

\section{PC: What is the future of solar energy in Honduras?}

MR: It is pretty well developed and I think it has a great future. The people are interested in the possibility of leasing systems. Leasing captures their attention, and we have had a good response. It's something you can't stop now. The people come into the office requesting systems. With solar systems, so many babies won't be born. People won't go all the way into town [where there is electricity] to grind grain. People will sell more in the rural pulperias. They'll like to be in the house more. Before we saw more emigration to San Pedro Sula, but it's depressing here. In the rural areas, you can now have light, television and blenders - without any risk. I hear about everything that happens in San Pedro Sula and I feel happy to be from a rural area. Now there is more development in rural zones. 
Women are capable of having goals. I want to continue studying business. Not only the math, but all aspects of business, including computers and Windows 95 . 


\section{Bibliography}

Becherer Hanan, Jean, ed. (n.d). Women and Energy: The International Network: Policies and Experience. Washington, D.C., The World Bank.

Cecelski, Elizabeth. (1998). Gender and Poverty Challenges in Scaling Up Rural Electricity Access. Paper for presentation at Village Power '98. Washington. DC.

Country Profiles: Renewable Energy and Energy Efficiency in Latin America and the Caribbean (1995). U.S. Export Council for Renewable Energy. xviii.

Covell, Philip W., and Hansen, Richard D. (1995). Full Cost Recovery in Photovoltaics Projects: Debunking the Myths about PV Equipment Subsidization. Enersol Associates.

Derrick, Anthony, Catherine Francis, Varis Bokalders. (1989) Solar Photovoltaic Products: A Guide for Development Workers. London: Intermediate Technology Publications, Ltd.

Hansen, R. and Martin J., (1987). Photovoltaics for Rural Electrification in the Dominican Republic, Produced by Enersol Associates and the University of Lowell Foundation for the Department of Energy.

Kotler, Philip (1997). Marketing Management: Analysis, Planning, Implementation, and Control. Upper Saddle River, NJ: Prentice-Hall, Inc.

Moore, Taylor. (July/August 1995). Developing Countries on a Power Drive [Online]. URL: http://www.epri.com/epri_journal/jul_aug95/develop.html.

Reddy, Amulya K.N., Wiliams Robert H., Johansson, Thomas B. (1997). Energy After Rio: Prospects and Challenges. New York: United Nations Publications.

Waring, Marilyn. (1988). If Women Counted: A New Feminist Economics. San Francisco: Harper. 234. 


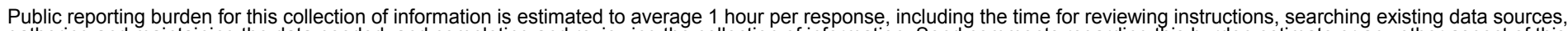

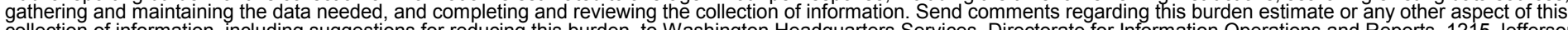

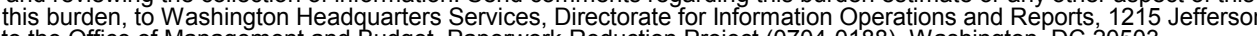
Davis Highway, Suite 1204, Arlington, VA 22202-4302, and to the Office of Management and Budget, Paperwork Reduction Project (0704-0188), Washington, DC 20503.
1. AGENCY USE ONLY (Leave blank)
2. REPORT DATE
November 2000
3. REPORT TYPE AND DATES COVERED Subcontractor Report

4. TITLE AND SUBTITLE

Solar-Based Rural Electrification and Microenterprise Development in Latin America: A Gender Analysis

5. FUNDING NUMBERS

TA: $5500-4000$

PO: 162244

6. AUTHOR(S)

Julie A. Smith

7. PERFORMING ORGANIZATION NAME(S) AND ADDRESS(ES)

Julie A. Smith

8. PERFORMING ORGANIZATION REPORT NUMBER

Boston, Massachusetts

9. SPONSORING/MONITORING AGENCY NAME(S) AND ADDRESS(ES)

National Renewable Energy Laboratory

1617 Cole Blvd. AGENCY REPORT NUMBER

Golden, CO 80401-3393

NREL/SR-550-28995

\section{SUPPLEMENTARY NOTES}

NREL Technical Monitor: Barbara C. Farhar, Ph.D.

\begin{tabular}{l|l|l} 
12a. DISTRIBUTION/AVAILABILITY STATEMENT & 12b. DISTRIBUTION CODE \\
National Technical Information Service & \\
U.S. Department of Commerce & \\
5285 Port Royal Road & \\
Springfield, VA 22161 &
\end{tabular}

13. ABSTRACT (Maximum 200 words)

Worldwide, an estimated 1.5 to 2 billion people do not have access to electricity, including 100 million in the Latin America region. Depending on the country, 30 to $90 \%$ of this unelectrified Latin American population lives in rural areas where geographic remoteness and low energy consumption patterns may preclude the extension of the conventional electricity grid. Women are heavily impacted by the energy scarcity given their role as primary energy procurers and users for the household, agricultural and small industrial subsectors in developing countries. As a result, women spend disproportionately more time engaged in energy-related activities like carrying water and searching for cooking fuel.

This paper describes the use of decentralized renewable energy systems as one approach to meet the energy needs of rural areas in Latin America. It outlines the advantages of a decentralized energy paradigm to achieve international development goals, especially as they relate to women. The paper studies Enersol Associates, Inc.'s Solar-Based Rural Electrification model as an example of a decentralized energy program which has merged energy and development needs through the local involvement of energy entrepreneurs, non-governmental organizations and community members.

14. SUBJECT TERMS

Latin America; electricity; gender; women; renewable energy; Enersol Associates; decentralized energy

17. SECURITY CLASSIFICATION OF REPORT Unclassified
18. SECURITY CLASSIFICATION OF THIS PAGE Unclassified
19. SECURITY CLASSIFICATION OF ABSTRACT

Unclassified
15. NUMBER OF PAGES 25

16. PRICE CODE

UL

Standard Form 298 (Rev. 2-89) Prescribed by ANSI Std. Z39-18 